\title{
Early evaluation of cocoa (Theobroma cacao L.) clones as intercrop in coconut gardens under red river region of Assam state, India
}

\author{
R. M. Phukon, J.C. Nath*, S. Sumitha ${ }^{1}$, H. P. Maheswarappa ${ }^{1}$ and Elain Apshara ${ }^{2}$ \\ AICRP on Palms, HRS, Kahikuchi, Guwahati-781 017, Assam, India \\ ${ }^{1}$ ICAR-Central Plantation Crops Research Institute, Kasaragod-671 124, Kerala, India \\ ${ }^{2}$ ICAR-Central Plantation Crops Research Institute, Regional Station, Vittal-574 243, Karnataka, India
}

(Manuscript Received: 05-10-2020, Revised:19-04-2021, Accepted:28-05-2021)

\begin{abstract}
A field experiment was conducted at Horticultural Research Station (AICRP on Palms), Kahikuchi of Assam Agricultural University for three consecutive years (2018-20) to study the initial performance of cocoa clones as intercrop in adult coconut (Cocos nucifera L.) garden spaced at $7.5 \mathrm{~m} \times 7.5 \mathrm{~m}$ taking 16 cocoa clones. Data on tree height, stem girth, number of pods, pod weight, number of beans pod ${ }^{-1}$, dry bean weight tree ${ }^{-1}$ year $^{-1}$ and single dry bean weight revealed significant variations among the 16 cocoa clones. Dried beans are the prime economic produce of cocoa, and single dry bean weight ranged from 0.95 to $1.4 \mathrm{~g}$. With respect to dry bean yield tree $\mathrm{e}^{-1}$, VTLC-20 recorded a significantly higher dry bean yield of $2.2 \mathrm{~kg} \mathrm{tree}^{-1}$ followed by VTLC-18 (1.5 kg tree $\left.{ }^{-1}\right)$ compared to other cocoa clones, and eight clones yielded more than $1.0 \mathrm{~kg}$ dry bean tree ${ }^{-1}$. Results showed that the number of leaves on the crown, number of inflorescences per palm and nut yield of coconut were not negatively affected; rather, there was an increase in the yield of coconut over the period.
\end{abstract}

Keywords: Assam, cocoa, coconut, dry bean, intercrop, VTLC clones

\section{Introduction}

India's share in global cocoa production is negligible; however, the crop has tremendous potential to develop as a monetary crop. The increasing domestic demand for chocolate industries should also drive for the area expansion and production of cocoa. India produced 19,866 tonnes of cocoa beans from 88,515 hectares with a productivity of $580 \mathrm{~kg} \mathrm{ha}^{-1}$ in the year 2020 (DCCD, 2020). Cocoa is grown primarily as an intercrop (under palms) in Andhra Pradesh, Karnataka, Kerala and Tamil Nadu, as the crop needs about 40-50 per cent shade. More than two-thirds of cocoa are grown in coconut (Thomas et al., 2010) and around a fifth with arecanut (Sujatha et al., 2011), followed by oil palm (Bhagya and Suresh, 2018) and rubber
(Rubber Board, 2011) plantations. Of late, Assam has became the latest state in the country to start cocoa cultivation, hitherto confined to southern states, with the availability of around one lakh hectares under coconut and arecanut gardens. Brahmaputra valley or red river region of Assam, has topographical proximity to the Equator, which means it has quintessential climatic conditions for cocoa cultivation. Cocoa entries screened for yield and quality were planted across AICRP on Palms centres to evaluate their performance under coconut and oil palm-based cropping systems (Maheswarappa et al., 2019). Coconut is an important perennial oilseed crop of Assam, mostly grown in the homestead garden as monocropping. The structure and orientation of the adult coconut

*Corresponding Author: jogeshn2001@yahoo.co.in 
canopy permit about 55 per cent active radiation to penetrate down (Nelliat, 1979) and the gardens spaced at $7.5 \mathrm{~m} \times 7.5 \mathrm{~m}$ offer wide purview for intercropping with suitable, biennial, seasonal and perennial crops, including cocoa, leading to a sustainable increase in the production and productivity per unit area (Nath et al., 2019). The increasing demand for cocoa in India has behoved many high yielding hybrids/varieties with resistance to biotic and abiotic stresses. Northeastern India is now all set to embark on massive cocoa cultivation; in Assam, evaluation of yield performance and yield stability of the cocoa clones is yet to be undertaken. Hence, a field experiment was carried out to identify suitable cocoa clones for intercropping in coconut gardens under Assam conditions.

\section{Materials and methods}

A field experiment was conducted in a 48-yearold Assam Green Tall coconut garden at the Horticultural Research Station (AICRP on Palms), Kahikuchi, Guwahati, situated at $26.30^{\circ} \mathrm{N}$ latitude $91.7^{0} \mathrm{E}$ longitude with an altitude of $64 \mathrm{~m}$ above MSL. The station enjoys a sub-tropical climate, with an annual rainfall of about $1500 \mathrm{~mm}$. The soil of the experimental site was alluvial clay-loam with a $\mathrm{pH}$ of 4.8 , low in available nitrogen $\left(231.2 \mathrm{~kg} \mathrm{ha}^{-1}\right)$, medium in available phosphorus $\left(23 \mathrm{~kg} \mathrm{ha}^{-1}\right)$ and available potassium (160.4 $\left.\mathrm{kg} \mathrm{ha}^{-1}\right)$ with an organic carbon of 0.45 per cent. Sixteen cocoa clones viz., VTLC-13, VTLC-15, VTLC-17, VTLC-18, VTLC-20, VTLC-23, VTLC-25, VTLC-28, VTLC-36, VTLC-38, VTLC-39, VTLC-40, VTLC-128, VTLC-4A, EYT, and VTLCH-1 (Hybrid) were received from ICARCentral Plantation Crops Research Institute, Regional Station, Vittal during 2014-15 and planted at a distance of $3.0 \mathrm{~m} \times 7.5 \mathrm{~m}$ in a single hedge system under $7.5 \mathrm{~m} \times 7.5 \mathrm{~m}$ spaced coconut garden with two replications in a randomized block design. The package of practices recommended by ICARCPCRI, Kasaragod were followed. Pruning was regularly done in the clones wherein unproductive chupons arising from the main trunk and fan branches were removed before the monsoon onset.

Growth characters such as tree height, stem girth, height at first branching and canopy volume were measured from representative cocoa trees.

Table 1. Growth characters of VTLC clones of cocoa as intercrop in coconut garden

\begin{tabular}{|c|c|c|c|c|c|c|}
\hline Cocoa clone & $\begin{array}{c}\text { Tree height } \\
\text { (m) }\end{array}$ & $\begin{array}{c}\text { Stem girth } \\
(\mathrm{cm})\end{array}$ & $\begin{array}{l}\text { Height at first } \\
\text { branching }(\mathrm{cm})\end{array}$ & $\begin{array}{c}\text { Canopy spread } \\
\text { E-W (m) }\end{array}$ & $\begin{array}{r}\text { N-S } \\
(\mathbf{m}) \\
\end{array}$ & $\begin{array}{c}\text { Area } \pi r l \\
\left(\mathbf{m}^{2}\right)\end{array}$ \\
\hline VTLC-13 & $1.95^{\mathrm{ef}}$ & $31.0^{\mathrm{cd}}$ & $0.5^{b}$ & $1.7^{\mathrm{fg}}$ & $1.8^{\mathrm{fgh}}$ & $4.54^{\mathrm{h}}$ \\
\hline VTLC-15 & $2.17^{b c}$ & $32.6^{b}$ & $0.5^{b}$ & $2.2^{\mathrm{b}}$ & $2.1^{\mathrm{d}}$ & $6.51^{\mathrm{e}}$ \\
\hline VTLC-17 & $2.21^{\mathrm{ab}}$ & $33.0^{\mathrm{b}}$ & $0.4^{\mathrm{c}}$ & $2.0^{\mathrm{c}}$ & $2.1^{\mathrm{d}}$ & $6.66^{\mathrm{de}}$ \\
\hline VTLC-18 & $2.24^{\mathrm{ab}}$ & $33.8^{b}$ & $0.6^{\mathrm{a}}$ & $2.3^{\mathrm{b}}$ & $2.4^{\mathrm{b}}$ & $7.37^{b}$ \\
\hline VTLC-20 & $2.28^{\mathrm{a}}$ & $36.0^{\mathrm{a}}$ & $0.6^{\mathrm{a}}$ & $2.5^{\mathrm{a}}$ & $2.6^{\mathrm{a}}$ & $8.44^{\mathrm{a}}$ \\
\hline VTLC-23 & $2.06^{\mathrm{cd}}$ & $30.5^{\text {cde }}$ & $0.5^{b}$ & $1.7^{\mathrm{ef}}$ & $1.8^{\mathrm{efg}}$ & $5.50^{\mathrm{fg}}$ \\
\hline VTLC-25 & $2.08^{\mathrm{de}}$ & $29.6^{\mathrm{efg}}$ & $0.4^{\mathrm{c}}$ & $1.8^{\mathrm{ef}}$ & $1.9^{\mathrm{ef}}$ & $5.62^{\mathrm{g}}$ \\
\hline VTLC-28 & $1.78^{\mathrm{g}}$ & $29.0^{\mathrm{fg}}$ & $0.4^{\mathrm{c}}$ & $1.6^{\mathrm{gh}}$ & $1.8^{\mathrm{fgh}}$ & $4.15^{\mathrm{i}}$ \\
\hline VTLC-36 & $1.75^{\mathrm{g}}$ & $27.4^{\mathrm{gh}}$ & $0.6^{\mathrm{a}}$ & $1.7^{\mathrm{ef}}$ & $1.6^{\mathrm{i}}$ & $4.30^{\mathrm{hi}}$ \\
\hline VTLC-38 & $1.89^{\mathrm{f}}$ & $28.3^{\mathrm{fg}}$ & $0.6^{\mathrm{a}}$ & $1.8^{\mathrm{de}}$ & $1.9^{\mathrm{e}}$ & $4.38^{\mathrm{hi}}$ \\
\hline VTLC-39 & $1.99^{\mathrm{def}}$ & $28.0^{\mathrm{fg}}$ & $0.5^{b}$ & $2.2^{\mathrm{b}}$ & $2.3^{b c}$ & $6.98^{\mathrm{cd}}$ \\
\hline VTLC-40 & $1.96^{\mathrm{def}}$ & $31.6^{\mathrm{bc}}$ & $0.4^{\mathrm{c}}$ & $1.9^{\mathrm{cd}}$ & $2.2^{\mathrm{cd}}$ & $7.02^{b c}$ \\
\hline VTLC-128 & $1.76^{\mathrm{g}}$ & $27.0^{\mathrm{gh}}$ & $0.6^{\mathrm{a}}$ & $2.0^{\mathrm{c}}$ & $2.1^{\mathrm{d}}$ & $5.84^{\mathrm{f}}$ \\
\hline VTLC-4A & $1.78^{\mathrm{g}}$ & $27.8^{\mathrm{gh}}$ & $0.5^{b}$ & $1.6^{\mathrm{gh}}$ & $1.7^{\mathrm{hi}}$ & $3.77^{j}$ \\
\hline VTLCH-1 & $1.88^{e f}$ & $29.0^{\text {def }}$ & $0.6^{\mathrm{a}}$ & $1.7^{\text {ef }}$ & $1.8^{\text {efg }}$ & $4.10^{\mathrm{hi}}$ \\
\hline EYT & $1.68^{g}$ & $25.7^{\mathrm{h}}$ & $0.5^{b}$ & $1.5^{\mathrm{h}}$ & $1.7^{\text {ghi }}$ & $3.42^{\mathrm{j}}$ \\
\hline $\mathrm{CD}(\mathrm{P}=0.05)$ & 0.12 & 1.82 & NS & 0.23 & 0.22 & 0.34 \\
\hline $\mathrm{CV} \%$ & 2.87 & 2.82 & 2.89 & 2.86 & 2.84 & 2.93 \\
\hline
\end{tabular}

Values followed by the same alphabet in a column show non-significant differences at 0.05 level 
The canopy area was calculated using the formula $\pi \mathrm{rl}$, where, $\mathrm{r}=(\mathrm{EW}+\mathrm{NS}) / 4$ and $1=\sqrt{ } \mathrm{r}^{2}+\mathrm{h}^{2}, \mathrm{~h}=$ canopy height.

The pod yield of individual trees in each clone during each harvest was recorded and given as average pod yield tree ${ }^{-1}$ year $^{-1}$ for three years after yield stabilization (2018-2020). Pod characteristics such as individual pod weight and bean number per pod were measured from five pods of each tree. Beans were fermented, dried and single dry bean weight (SBW) and dry bean yield (DBY) tree ${ }^{-1}$ year $^{-1}$ was recorded. The data collected regarding various parameters of growth and yield traits were analysed statistically as described by Panse and Sukhatme (1985).

\section{Results and discussion}

\section{Tree characters}

As cocoa has a cauliflorous bearing habit, the tree height and stem girth are correlated with plant vigour, which directly relates to bearing. In the present study, clonal differences existed for tree height and stem girth (Table 1). The trees of VTLC-128, VTLC-28, VTLC-36, VTLC-4A and EYT showed short stature with height ranging from $1.68 \mathrm{~m}$ to $1.78 \mathrm{~m}$, while the trees of VTLC-20, VTLC-17 and VTLC-18 had a height of around $2.28 \mathrm{~m}$. A few taller trees were observed in eight other clones with more than $2 \mathrm{~m}$ in height. The trunk circumference differed significantly
Table 2. Pod and yield characteristics of VTLC clones of cocoa as intercrop in coconut garden

\begin{tabular}{|c|c|c|c|}
\hline $\begin{array}{l}\text { Cocoa } \\
\text { clone }\end{array}$ & $\begin{array}{c}\text { Weight of } \\
\text { pod } \\
\text { (g) }\end{array}$ & $\begin{array}{l}\text { Single dry } \\
\text { bean weight } \\
\text { (g) }\end{array}$ & $\begin{array}{c}\text { Dry bean } \\
\text { yield } \\
\left(\mathrm{kg} \mathrm{tree}^{-1}\right)\end{array}$ \\
\hline VTLC-13 & $397.0^{\text {cde }}$ & $1.1^{\mathrm{c}}$ & $1.2^{\mathrm{d}}$ \\
\hline VTLC-15 & $391.4^{\mathrm{cde}}$ & $1.1^{\mathrm{c}}$ & $1.1^{\mathrm{e}}$ \\
\hline VTLC-17 & $407.5^{\mathrm{cd}}$ & $1.2^{\mathrm{b}}$ & $1.3^{\mathrm{c}}$ \\
\hline VTLC-18 & $462.0^{\mathrm{b}}$ & $1.2 \mathrm{~b}$ & $1.5^{\mathrm{b}}$ \\
\hline VTLC-20 & $482.0^{\mathrm{a}}$ & $1.4^{\mathrm{a}}$ & $2.2^{\mathrm{a}}$ \\
\hline VTLC-23 & $376.0^{e f}$ & $1.2 \mathrm{~b}$ & $1.0^{\mathrm{f}}$ \\
\hline VTLC-25 & $366.5^{\mathrm{fg}}$ & $1.1^{\mathrm{c}}$ & $0.86^{\mathrm{h}}$ \\
\hline VTLC-28 & $350.0^{\mathrm{gh}}$ & $1.1^{\mathrm{c}}$ & $0.91^{\mathrm{gh}}$ \\
\hline VTLC-36 & $370.4^{\mathrm{ef}}$ & $0.95^{\mathrm{d}}$ & $1.0^{\mathrm{f}}$ \\
\hline VTLC-38 & $330.0^{\mathrm{hi}}$ & $1.0^{\mathrm{d}}$ & $0.87^{\mathrm{h}}$ \\
\hline VTLC-39 & $315.0^{\mathrm{i}}$ & $0.96^{\mathrm{d}}$ & $0.97^{\mathrm{fg}}$ \\
\hline VTLC-40 & $387.0^{\mathrm{de}}$ & $0.97^{\mathrm{d}}$ & $1.0^{\mathrm{f}}$ \\
\hline VTLC128 & $412.0^{\mathrm{c}}$ & $1.0^{\mathrm{d}}$ & $0.97^{\mathrm{f}}$ \\
\hline VTLC-4A & $397.0^{\text {cde }}$ & $1.1^{\mathrm{c}}$ & $0.91^{\mathrm{gh}}$ \\
\hline VTLCH-1 & $387.6^{\text {cde }}$ & $1.1^{\mathrm{c}}$ & $1.0^{\mathrm{f}}$ \\
\hline EYT & $310.6^{\mathrm{i}}$ & $0.98^{\mathrm{d}}$ & $0.58^{i}$ \\
\hline $\mathrm{CD}(\mathrm{P}=0.05)$ & 23.8 & 0.06 & 0.07 \\
\hline CV\% & 2.88 & 2.90 & 3.18 \\
\hline
\end{tabular}

Values followed by the same alphabet in a column show nonsignificant differences at 0.05 level

among the clones. In the case of height at first branching, it was found to be non-significant among the clones. Significantly the maximum canopy area

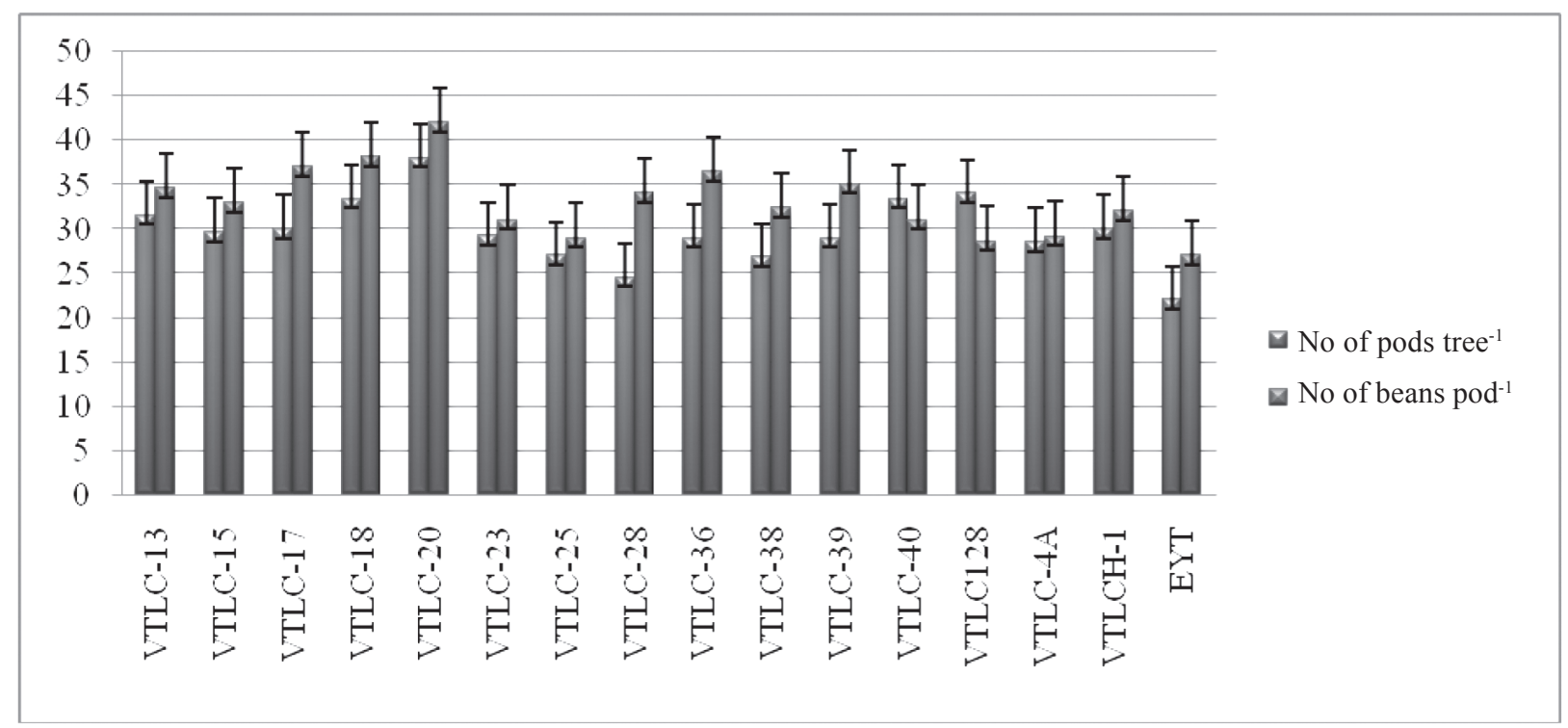

Fig. 1. Number of pods tree ${ }^{-1}$ and numbers of beans $\operatorname{pod}^{-1}$ of cocoa clones 


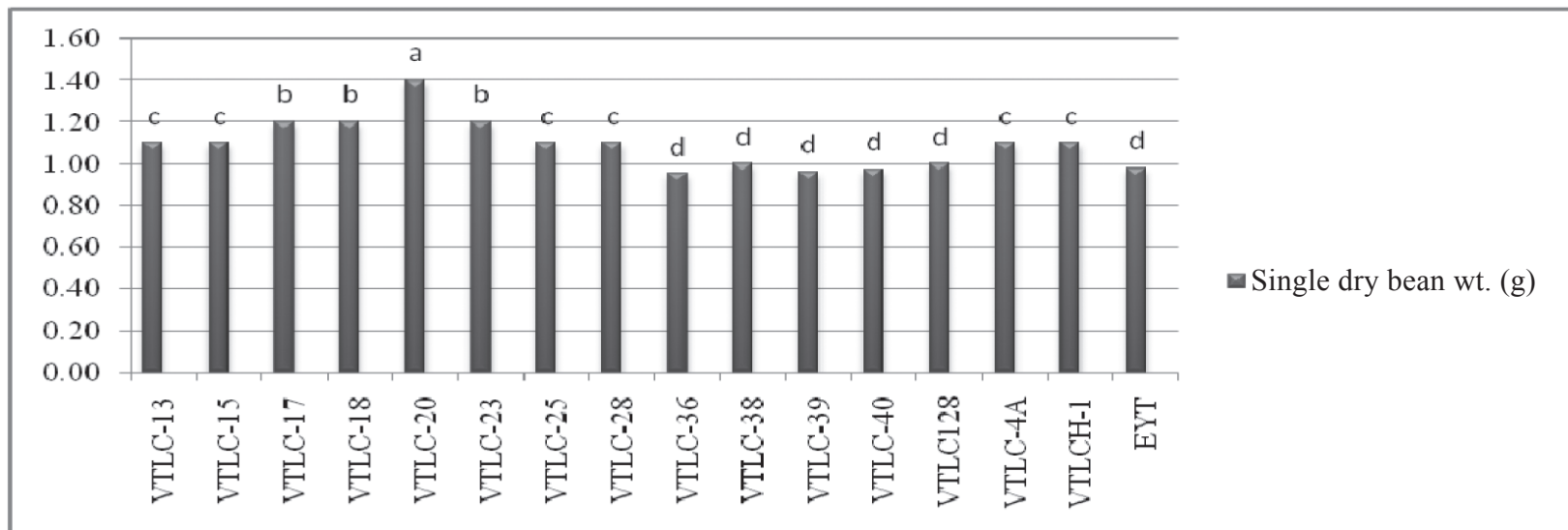

*Values followed by a same alphabet show non-significant differences between clones at 0.05 level

Fig. 2. Single dry bean weight (g) of cocoa clones

was recorded in cocoa clone VTLC-20 $\left(8.44 \mathrm{~m}^{2}\right)$. In general, a cocoa tree with good stem girth, more numbers of fan branches and canopy spread reflects the vigour of the trees, indirectly favouring higher yield. The differences in the tree height and stem girth of cocoa have been attributed to various factors such as soil moisture, availability of nutrients, environmental factors and genetic factors of the tree. Similar differences in the tree height and stem girth of clones and hybrids have been noted by Apshara et al. (2009), Thondaiman et al. (2013), Sumitha et al. (2018) and Bhalerao et al. (2018). A small canopy with a $3.42 \mathrm{~m}^{2}$ spread was observed in the clone EYT, whereas a voluminous canopy $\left(8.44 \mathrm{~m}^{2}\right)$ was observed in the clone VTLC- 20. Pruning is an important operation in cocoa, especially when it is grown as an intercrop. Maintenance of optimum canopy shape involves pruning certain branches as it is known in cocoa that highly shaded leaves do not show photosynthetic activity and penetration of sunlight to stimulate cocoa flowering and fruit setting (Uchoi et al., 2018).

\section{Pod, bean and yield characters}

In general, cocoa yield is determined by yield contributing traits such as the number of pods, dry bean yield tree ${ }^{-1}$ year $^{-1}$ and pod value (Thondaiman et al., 2013). The number of pods tree ${ }^{-1}$ year $^{-1}$ showed significant variation among the cocoa clones (Fig. 1), and VTLC-20 recorded the highest number of pods tree ${ }^{-1}$ year $^{-1}$ (38.0) followed by VTLC-40 (33.4), whereas the clone VTLCH-1 recorded the lowest number of pods tree ${ }^{-1}$ year $^{-1}(22.0)$. In respect to pod characters, the pod weight and the number of beans pod $^{-1}$ were significantly different among the cocoa clones with higher pod weight and the number of beans pod ${ }^{-1}$ observed in VTLC-20 (482.0 $\mathrm{g}$ and 42.0 respectively) followed by VTLCH-18 (462.0 g and 38.1 respectively) (Table 2 and Fig. 1). The number of beans decides the total weight of beans per pod. Glendinning (1963) observed that if a pod was too small for the inherent number of beans to be present at their inherent size, the number of beans was reduced so that their inherent size was attained; if the pod was larger than that required for the full

Table 3. Growth and yield of coconut in the experimental garden

\begin{tabular}{|c|c|c|c|c|}
\hline \multirow[t]{2}{*}{ Parameters } & \multirow{2}{*}{$\begin{array}{c}\text { Pre-treatment } \\
\text { observations } \\
(2010-11 \text { to } 2012-13)\end{array}$} & \multicolumn{3}{|c|}{ Experimental period } \\
\hline & & 2017-18 & 2018-19 & 2019-2020 \\
\hline No. of functional leaves & 29.8 & 29.5 & 30.1 & 31.0 \\
\hline No. inflorescence palm ${ }^{-1}$ & 11.5 & 11.0 & 12.1 & 11.9 \\
\hline Nut yield palm-1 year ${ }^{-1}$ & 55.4 & 61.3 & 63.0 & 65.8 \\
\hline Nut yield ha-1 year-1 $^{-1}$ & 9709 & 10734 & 11025 & 11515 \\
\hline
\end{tabular}


number of beans to attain their inherent size, the beans might increase in size above the inherent value. It is essential to select cocoa genotypes with less than 35 beans per pod to utilize the clones in crop improvement or commercial plantations (Sumitha et al., 2018).

As beans are the economic part of the cocoa crop, in the present study, single dry bean weight was observed from $0.95 \mathrm{~g}$ to $1.4 \mathrm{~g}$ (Fig. 2). Among clones, VTLC-20 recorded a significantly higher dry bean yield of $2.2 \mathrm{~kg}$ tree ${ }^{-1}$ followed by VTLC-18 $\left(1.5 \mathrm{~kg}\right.$ tree $\left.^{-1}\right)$ than other cocoa clones. In total, eight clones recorded more than $1 \mathrm{~kg}$ dry bean yield tree ${ }^{-1}$. Enriquez and Soria (1968) studied the variability in bean size, shell per cent and the number of beans per pod in cocoa clones of different genetic origins and found significant differences. The dry bean recovery was significantly influenced by the number of beans pod ${ }^{-1}$, bean weight (fresh \& dry), single bean weight (fresh \& dry) and fermentation method. A similar phenomenon was observed by Thondaiman et al. (2013), Minimol et al. (2016), Sajeevkumar et al. (2017) and Vithya et al. (2018).

\section{Growth and yield of coconut}

The mean data of three years from 2017-18 to 2019-20 showed that the number of leaves on the crown, number of inflorescence and nut yield palm $^{-1}$ did not differ significantly in the coconut intercropped with cocoa clones (Table 3). This indicated that cocoa clones could be grown as intercrops in coconut without affecting the yield of coconut. However, an increase in nut yield from 55 nuts palm ${ }^{-1}$ year ${ }^{-1}$ to 65 nuts palm $^{-1}$ year $^{-1}$ was observed. The favorable microclimatic conditions due to intercropping combined with improved microbial activities and soil fertility status, which in turn have increased the coconut yield. The enhancement in nut yield of the coconut by intercropping is also supported by the findings of Bhalerao et al. (2018) and Nath et al. (2019).

\section{Conclusion}

Based on growth and yield parameters assessed in the present study, it is indisputable that the performance of all the clones of cocoa in terms of yield is on par in the juvenile phase of the establishment (six years after planting). However, a continuous evaluation is required to assess their yield potential and quality parameters when grown as intercrop in coconut gardens under Assam.

\section{Acknowledgement}

The first and second authors are highly thankful to ICAR-All India Coordinated Research Project on Palms and Director of Research (Agriculture), $\mathrm{AAU}$, Jorhat, for the financial support provided during the study period.

\section{References}

Apshara, E.S., Bhat, V.R., Ananda, K.S., Nair, R.V. and Suma, D. 2009. Evaluation and identification of high yielding trees in Nigerian cocoa germplasm. Journal of Plantation Crops 37(2): 111-116.

Bhagya, H.P. and K. Suresh. 2018. Carbon sequestration potential in oil palm-cocoa cropping system grown in Andhra Pradesh under irrigated conditions. International Journal of Current Microbiology and Applied Sciences 7(5): 358-362.

Bhalerao, P.P., Maheswarappa, H.P., Sumitha, S. and Elain Apshara, S. 2018. Performance of cocoa clones as intercrop in coconut gardens under south Gujarat condition. International Journal of Innovative Horticulture 7(2): 120-122.

DCCD. 2020. Directorate of Cashew and Cocoa Development. (http://dacnet.nic.in /cashewcocoa/stat2.htm). Accessed on 30 January 2021.

Enriquez, G. and Soria, J.V. 1968. The variability of certain bean characteristics of cacao (Theobroma cacao L.). Euphytica 17: 114-120.

Glendinning, D.R. 1963. The inheritance of bean size, pod size and number of beans per pod in cocoa (Theobroma cacao L.), with a note on bean shape. Euphytica 12: 311-322.

Maheswarappa, H. P., Sumitha, S. and Elain Apshara. 2019. Performance of cocoa varieties/ hybrids as intercrop in coconut/oil palm gardens in different regions of India. In: Proceedings of International Meeting on Asia Pacific Cocoa Breeders' Working Group (APCBWG), 20-25 May, 2019, ICAR-CPCRI, Kasaragod, p. 42.

Minimol, J.S., Suma, B., Ummer, M., and Chithira, P.G. 2016. Genetic improvement of cocoa by developing superior hybrids. Journal of Tropical Agriculture 53(2): 157-165.

Nath, J.C., Deka, K.K., Maheswarappa, H.P. and Sumitha. S. 2019. System productivity enhancement in coconut (Cocos nucifera) garden by intercropping with flower crops in Assam. Indian Journal of Agricultural Sciences 89(11): 1842-1845. 
Nelliat, E.V. 1979. Prospects of multiple cropping. In: Multiple Cropping in Coconut and Arecanut Garden. (Eds.) Nelliat, E.V. and Bhat, K.S. CPCRI, Kasaragod, Kerala. Technical Bulletin 3: 6-23.

Panse, V.G. and Sukhatme, P.V. 1985. Statistical Methods for Agricultural Workers, 4th Edn. Indian Council of Agricultural Research, New Delhi.

Rubber Board. 2011. Rubber Growers Guide, pp.17-19.

Sajeevkumar, S.S., Minimol, J.S., Ajmal, P.M. and Suma. B. 2017. Diversity analysis of KAU released cocoa (Theobroma cacao L.) varieties based on morphological parameters. Journal of Tropical Agriculture 55(1): 81-86.

Sujatha, S., Ravi Bhat, Balasimha, D. and Apshara, E.S. 2011. Arecanut based inter/ mixed cropping system. In: Arecanut Based Cropping/Farming System. (Eds.) Thomas, G.V., Krishnakumar, V., Maheswarappa, H.P., Ravi Bhat and Balasimha, D. Central Plantation Crops Research Institute, Kasaragod. pp. 6-26.

Sumitha, S., Balakrishnan, S., Shoba, N., Kumar, M., Jeyakumar, P. and Jegadeeswari, V. 2018. Growth and yield performance of cocoa (Theobroma cacao L.) varieties under Tamil Nadu condition. Journal of Pharmacognosy and Phytochemistry 7(5): 591-594.

Thomas, G.V., Krishanakumar, V., Maheswarappa, H.P. and Palaniswami, C. 2010. Coconut Based Cropping/ Farming Systems. Central Plantation Crops Research Institute, Kasaragod, India. pp.231.

Thondaiman, V., Rajamani, K., Senthil, N., Shoba, N. and Joel, A. J. 2013. Variability studies and identification of high yielding plus trees of cocoa (Theobroma cacao L.) in Tamil Nadu. African Journal of Agricultural Research 8(26): 3444-3453.

Uchoi, A., Shoba, N., Balakrishnan, S., Gopal, N.O. and Uma, D. 2018. Impact of canopy management on flowering and yield attributes of cocoa (Theobroma cacao L.) under tropical condition of Tamil Nadu. International Journal of Chemical Studies 6(5): 629-633.

Vithya, K., Balakrishnan, S., Jegadeeswari, V. and Jeyakumar, P. 2018. Evaluation of cocoa (Theobroma cacao L.) genotypes for pod and bean characters. Journal of Plantation Crops 46(3): 169-172. 